\title{
THE ROLE OF TRADE BARRIERS IN INTERNATIONAL TRADE IN METALLURGICAL INDUSTRY OF UKRAINE
}

\author{
Fato Sharoian ${ }^{1}$
}

\begin{abstract}
The purpose of the paper is to analyze and present the role of the metal-lurgical industry for the economy of Ukraine and evaluate the impact of trade re-strictions on the international activity of the metallurgical industry of Ukraine. As a result, this study evaluated the risks of international activities of metallurgical enter-prises of Ukraine with key partner countries. Methodology. Assessment of the role of the metallurgical industry for the Ukrainian economy and the extent of the impact of trade barriers on international activities is based on several statistical data and a few methods and rules for their analysis. Their use will allow managers of metallurgical companies to form a strategy for the development of the enterprise in international markets and quickly respond to changes in the external market situation. These methods include statistical analysis, strategic segmentation, deductive and inductive methods, data comparison method, forecasting and risk assessment. Results. Per capita steel consumption growth rates have shown positive dynamics since 2010. Volatility levels of per capita steel consumption of the population is significantly lower than the growth of world GDP. Against the backdrop of slowing global GDP growth rate of steel consumption continues to grow. According to the level of consumption of steel per capita, the author singled out three stages in the development of countries. The share of exports of products of the metallurgical industry of Ukraine in 2020 amounted to $18.3 \%$ in monetary terms. This indicator is the second after the volume of exports of agricultural products. Among the total export of steel products in Ukraine $95 \%$ are engaged in export of ferrous metals, which is a raw product. The trade balance of Ukraine in the trade of metallurgical products has been decreasing since 2018 amid a decrease in export volumes and has not yet reached the level of 2016. According to the World Trade Organization, at the end of 2020, there were 3,208 non-tariff trade barriers in the world regarding trade in metals and metal products. In terms of the number of anti-dumping measures, the market of metals and metal products ranks first - 843 measures out of 2160 measures for all product groups. This tool is used by countries to protect the domestic market and as a tool in international competition. As a result of a matrix analysis of the rates and volumes of growth of Ukraine's metallurgical products in the context of partner countries and the number of introduced trade barriers, the countries with the highest risk in international activities and the most promising sales markets were identified. The Russian Federation and the United States are identified as the countries with the highest risk of the impact of trade barriers on international activities for Ukrainian metallurgical companies. The most promising sales markets are Saudi Arabia and Italy. Practical implications. With the help of the results of this paper, managers of metallurgical enterprises in Ukraine can form and adjust the strategic directions for the development of companies in the framework of international activities.
\end{abstract}

Key words: international trade, metallurgy, trade barriers, Ukrainian metallurgical sector, export strategy.

JEL Classification: F13, L25, O24, P33

\section{Introduction}

The metallurgical industry is one of the most strategically important for the Ukrainian economy. This is confirmed by the volume of revenues to the state budget from enterprises of the metallurgical industry, the number of people employed in the industry and the volume of foreign exchange earnings.

According to the State Statistics Service of Ukraine, the volume of exports of metallurgical products in 2020 decreased compared to 2014 by $40 \%$ in monetary

Corresponding author:

${ }^{1}$ Taras Shevchenko National University of Kyiv, Ukraine.

E-mail: fato.sharoian@i.ua terms (State Statistics Service of Ukraine, 2020). This factor determines the problem of analysis of causal factors influencing the international trade of products of the metallurgical industry of Ukraine to diversify the international activities of enterprises of the metallurgical industry and increase the economic security of Ukraine.

One of the most important factors influencing Ukraine's international trade is the role of trade barriers in the metallurgical industry. Trade barriers are an

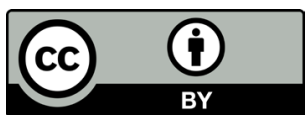

This is an Open Access article, distributed under the terms of the Creative Commons Attribution CC BY 4.0 
effective method of protecting the domestic market of the initiating country and an important tool of international competition. According to the WTO classification, trade barriers are divided into tariff and non-tariff trade barriers. In turn, import and export tariffs, ad valorem and specific tariffs and combined act as tariff barriers. Non-tariff trade barriers are divided into technical barriers, sanitary and phytosanitary measures, quantitative restrictions, tariff-rate quotas, export subsidies, safeguards, countervailing and anti dumping barriers. This tool became especially popular in 2016, when the largest number of trade barriers was recorded. In 2016, the US government imposed several large-scale trade barriers, including $25 \%$ antidumping barriers on imports of metallurgical products to all suppliers.

That is why the issue of updating risk management is important in the analysis of international trade in products of the metallurgical industry of Ukraine in the framework of all international activities by analyzing the impact of international trade barriers on the metallurgical industry of Ukraine.

\section{The global steel industry}

According to the World Steel Association, since 2003 there has been an annual increase in world steel production, which indicates the importance of ferrous metallurgy and its sustainable development. At the same time, we can say about a close relationship between world steel production and GDP. On average, for every \$100. US GDP growth is required to produce $2 \mathrm{~kg}$ of steel (World Steel Association, 2019).
World steel production in 2019 amounted to 1,875 million tons, which is $2.7 \%$ more than the previous year. For comparison, the level of world GDP growth in 2019 was $2.3 \%$. The largest steel producer is the Asian region, which produces $72 \%$ of the world's steel. That is why Asian markets are very important in the process of redistribution of steel production and consumption, which in turn affects world prices for metallurgical products.

For comparison, Figure 1 shows comparative graphs of per capita steel consumption and the dynamics of global GDP growth according to the World Bank (World Bank, 2021). From the data of the figure, we see that the volume of steel consumption per capita has a positive trend, and shows lower volatility compared to world GDP growth. This fact confirms the growing importance of the metallurgical industry in international markets and the development of countries.

It is also important to note that the volume of steel consumption characterizes the level of technological development of the national economy. Analysis of the dy-namics of GDP per capita and consumption of rolled steel on the example of countries such as the United States and Japan, allows us to identify three stages of economic development:

1. Steel consumption is growing, outpacing GDP growth, and reaching a maximum of $700-800 \mathrm{~kg} /$ person per year. This indicator characterizes the economic development due to industry.

2. During the transition from the industrial to the post-industrial system of the economy, metal consumption decreased, but was accompanied by a further increase in GDP.

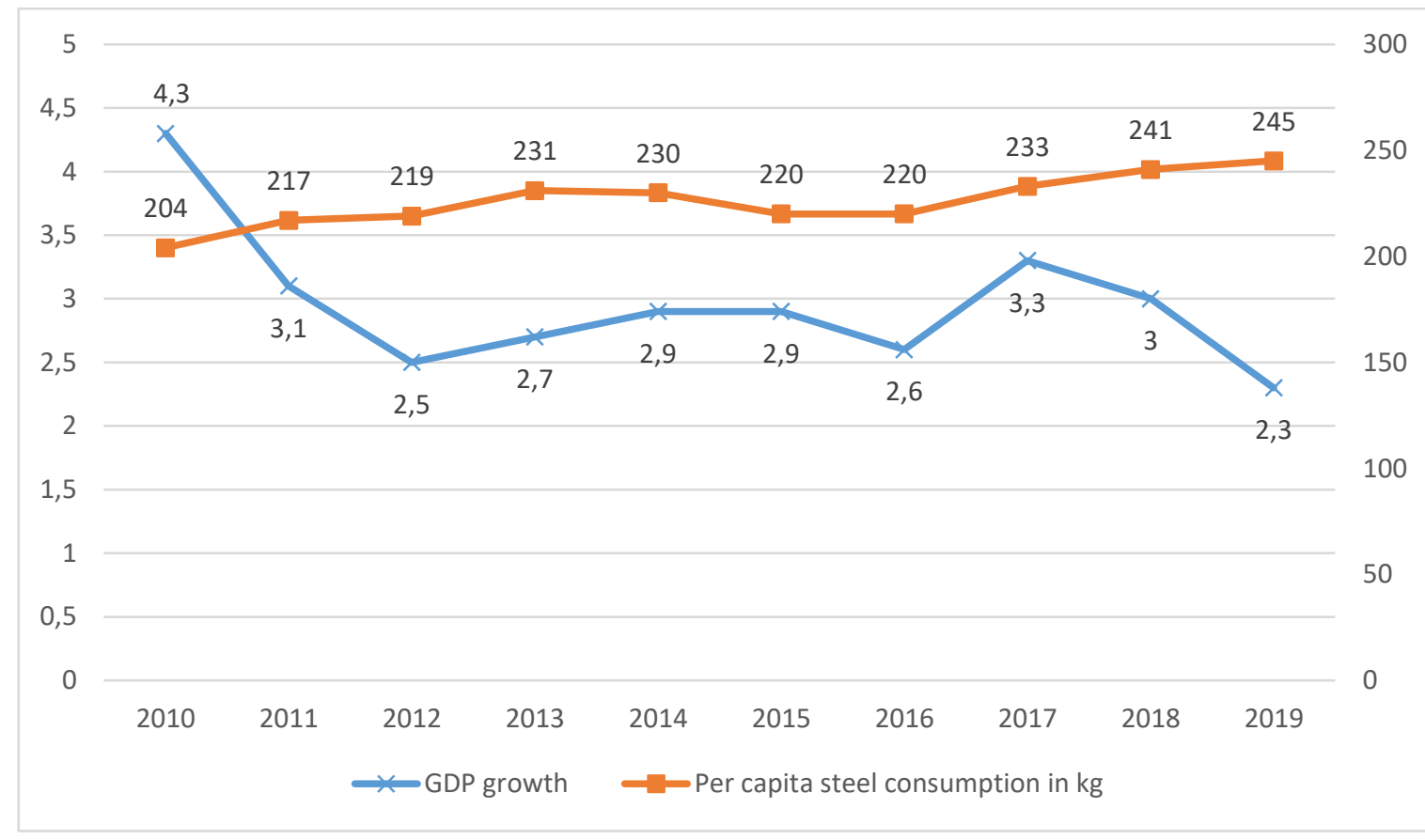

Figure 1. The level of steel consumption per capita compared to world GDP growth 
3. In a post-industrial economy, rolled consumption stabilized at $400-600 \mathrm{~kg} /$ person per year with a subsequent gradual decrease with moderate GDP growth.

\section{Ukrainian metallurgical sector}

According to the results of 2019, Ukraine continues to rank 13th in terms of steelmaking in the world. According to the State Statistics Service, the share of ex-ports of metallurgical products in total exports of Ukrainian goods in 2020 is $18.3 \%$, which is the second largest export after the group of products of plant origin - $24.2 \%$ (State Statistics Service of Ukraine, 2020).

It is worth noting the importance of ferrous metallurgy for Ukrainian exports, the basis of which, in addition to agricultural goods, are metals and metal products. Thus, the share of base metals and their products in 2020 amounted to $18.3 \%$ of total exports, compared to 2019, the volume of exports in monetary terms decreased by $11.9 \%$. According to the data shown in Figure 2, it is possible to analyze the commodity structure of both exports of goods of Ukraine and commodity groups of the metallurgical industry of Ukraine according to 2020.

The main item of exports of base metals and articles thereof in 2020 are ferrous metals and articles thereof (95\% of exports of metallurgical products). Among these $95 \%$ of ferrous metal exports, only $10 \%$ are ferrous metal products. Thus, it can be argued that $85 \%$ of exports of metallurgical products are raw materials and semi-finished products (State Statistics Service of Ukraine, 2020). This factor suggests that Ukraine is still a raw material appendage for partner countries.
The reduction in exports in 2020 amounted to $11.9 \%$ compared to 2019, in 2019 the reduction was $11.8 \%$. The dynamics of exports and imports of products of the metallurgical industry of Ukraine can be analyzed according to the data in Figure 3.

The decline in exports of metallurgical products in 2020 is due to lower con-sumption in international markets in the context of the COVID19 pandemic, which led to the suspension of many enterprises and projects.

The decline in imports of metallurgical products of Ukraine has a lower rate compared to exports. This factor carries risks of Ukraine's economic security, despite the positive trade balance. This trend describes the significant impact of trade barriers in international markets, which have increased their relevance over the past 5 years. This is one of the reasons for the urgency of reducing the risks of international activities of metallurgical enterprises through the diversification of international activities.

\section{Trade barriers in metallurgical industry}

According to the World Trade Organization, at the end of 2020, there were 3,208 non-tariff trade barriers in the world regarding trade in metals and metal products. In figure 4 shows the types of non-tariff barriers to trade in metals at the end of 2019. The most common types of barriers to trade in metals are technical barriers and anti-dumping measures (2003 measures and 843 measures at the end of 2019, respectively) (World Trade Organization, 2021).

It is important to note that in terms of the number of anti-dumping measures, the market of metals and metal products ranks first - 843 measures out of 2160 measures for all product groups. This tool is used

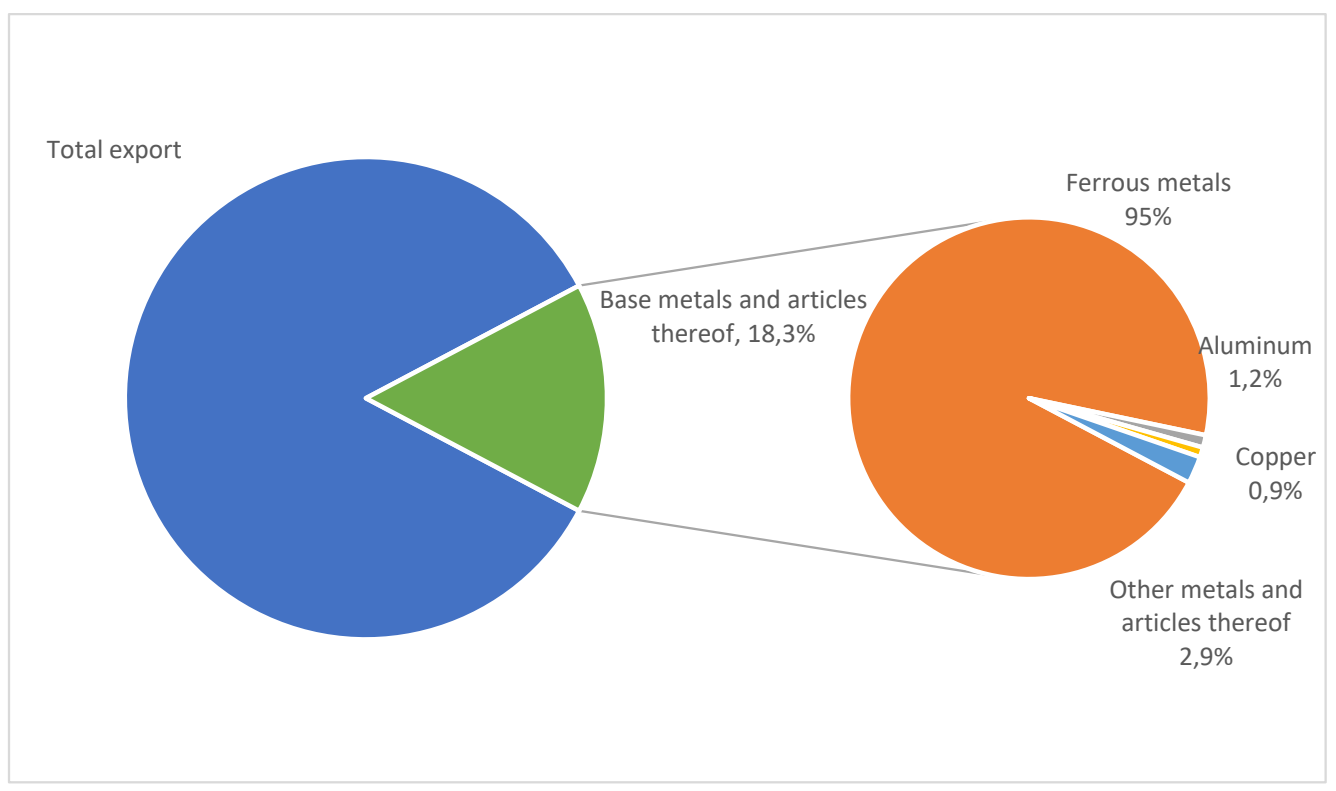

Figure 2. Commodity structure of Ukraine's exports, share of commodity groups of the metallurgical industry 
Vol. 2 No. 3, 2021

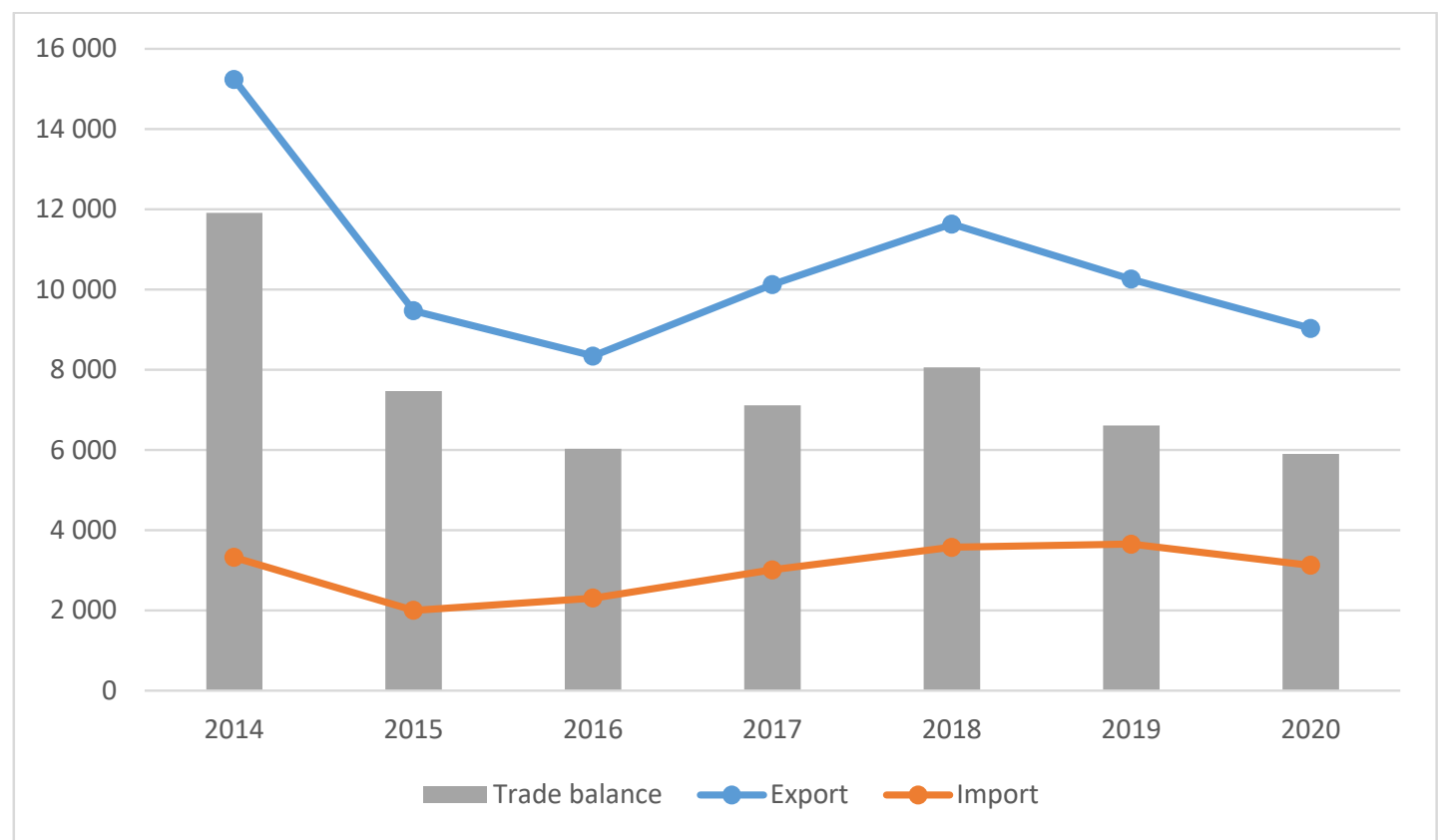

Figure 3. Dynamics of international trade in metallurgical products of Ukraine, million USD

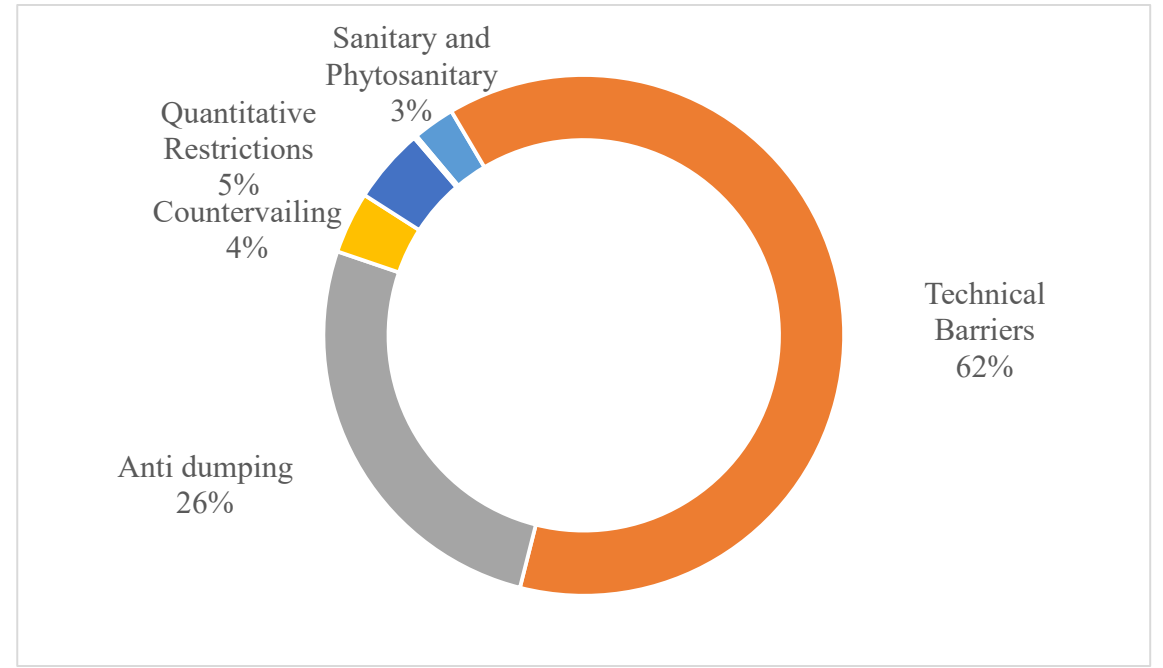

Figure 4. Non-tariff barriers to trade in metals in the world as of December 31, 2019

by countries to protect the domestic market and as a tool in international competition, as the metallurgical industry is capital-intensive and labor-intensive (Novikov, Zemlyanskaya, 2021). In terms of the dynamics of the use of non-tariff barriers in Figure 5 shows the number of measures introduced to restrict trade in metals and metal products.

Since 2014, there has been a steady increase in the number of non-tariff barriers, which is a reaction to the growth of world production capacity and the aggrava-tion of trade relations between producer countries. It is with the help of non-tariff barriers that actions in international competition between countries were actively carried out (Shirinova, 2018). A special aggravation in the metallurgical market occurred after the introduction of anti-dumping measures by the United
States on imports of steel and metallurgical products, which strongly affected the world metallurgical market.

However, in 2020, the number of non-tariff barriers to metals and metal products in the world has decreased significantly. The main reason for this was the factor COVID-19, which won the lockdown in almost all countries. As a result, consumption of steel and metal products has decreased in many countries, which has reduced the relevance of the introduction of non-tariff barriers in 2020.

Thus, the increase in steel production capacity in the world leads to the application of active protectionist measures, which are manifested in trade barriers in international markets.

Considering the above analysis of the dynamics and structure of international trade in metallurgical 


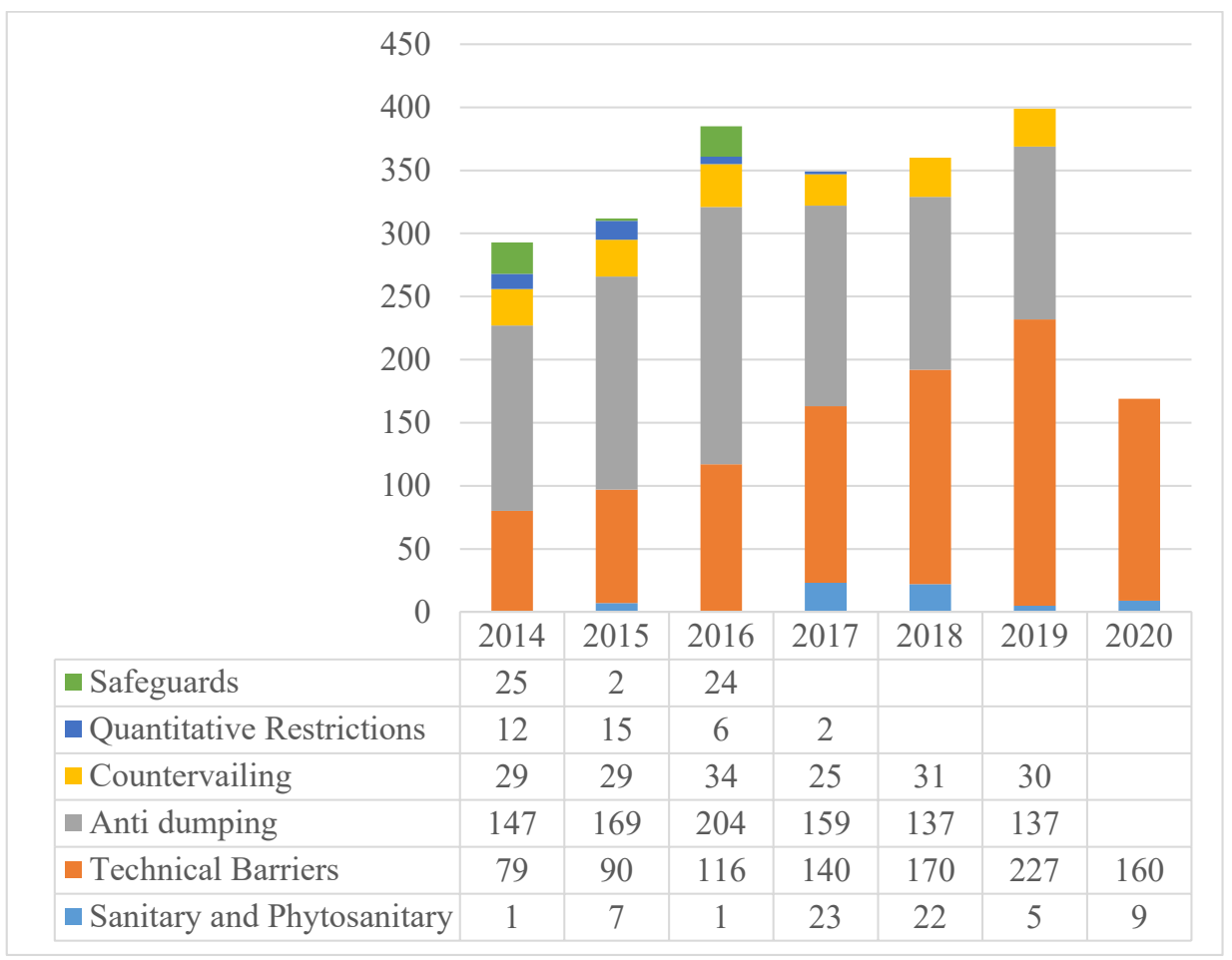

Figure 5. Dynamics of the number of non-tariff barriers in trade in metals and articles thereof by types of non-tariff restrictions

products, and the emergence of new sources of risks to trade barriers, it is proposed to conduct a matrix assessment of source risks and prospects of trade barriers to export activities of metallurgical enterprises of Ukraine. The effective matrix of key importers of Ukrainian metallurgical products in relation to the number of introduced trade barriers can be considered in Figure 6. Statistics of 2019 were taken as a basis for risk assessment, as 2020 in a pandemic may reflect a non-standard picture.

The given matrix on the $\mathrm{X}$ axis shows data on the volume of exports of metallurgical products to Ukraine in million USD, along the $\mathrm{Y}$ axis - the growth rate of export volumes in 2019 compared to 2018, the diameter of the circle is determined by the number of existing non-tariff trade barriers in relation to trade in metallurgical products.

This matrix can be used to assess risks in trade with key countries-importers of Ukrainian metallurgical products. According to the data, exports of metallurgical products to China can be attributed to the average level of risk. Because the country plays an important role in international markets for metallurgical products and actively applies non-tariff trade restrictions, which in most cases apply as appropriate measures against barriers that are initiated against China.

The middle level of risk also includes European countries (Poland, Bulgaria, and Germany), as the number of existing trade barriers is relatively small
(104 cur-rent trade restrictions at the end of 2019 in relation to metallurgical products). Also, the volume of exports of metallurgical products to EU countries is much higher compared to other regions of international trade (the total share of exports of metallurgical products to Ukraine to Italy, Poland, Bulgaria, and Germany is $24 \%$ of total exports).

The riskiest export markets under this matrix include the United States and the Russian Federation. In the first case, a significant role of risk is played by the number of existing trade barriers to trade in metallurgical products (466 barriers at the end of 2019). In the second case, political risks play a significant role in the form of trade barriers, with exports to the Russian Federation second only to Italy.

The most promising markets for the development of international trade in metallurgical products are Italy and Saudi Arabia. Prospects for the development of trade with Italy are determined by the significant volume of consumption and the low level of trade barriers in relation to Ukrainian metallurgical products. The second reason is that Italy is a logistically convenient trading hub for sales throughout Europe and North Africa. Saudi Arabia is a promising market for the development of international activities for enterprises in the metallurgical industry of Ukraine, as this market has a high growth rate of construction and development of the oil and gas industry. 


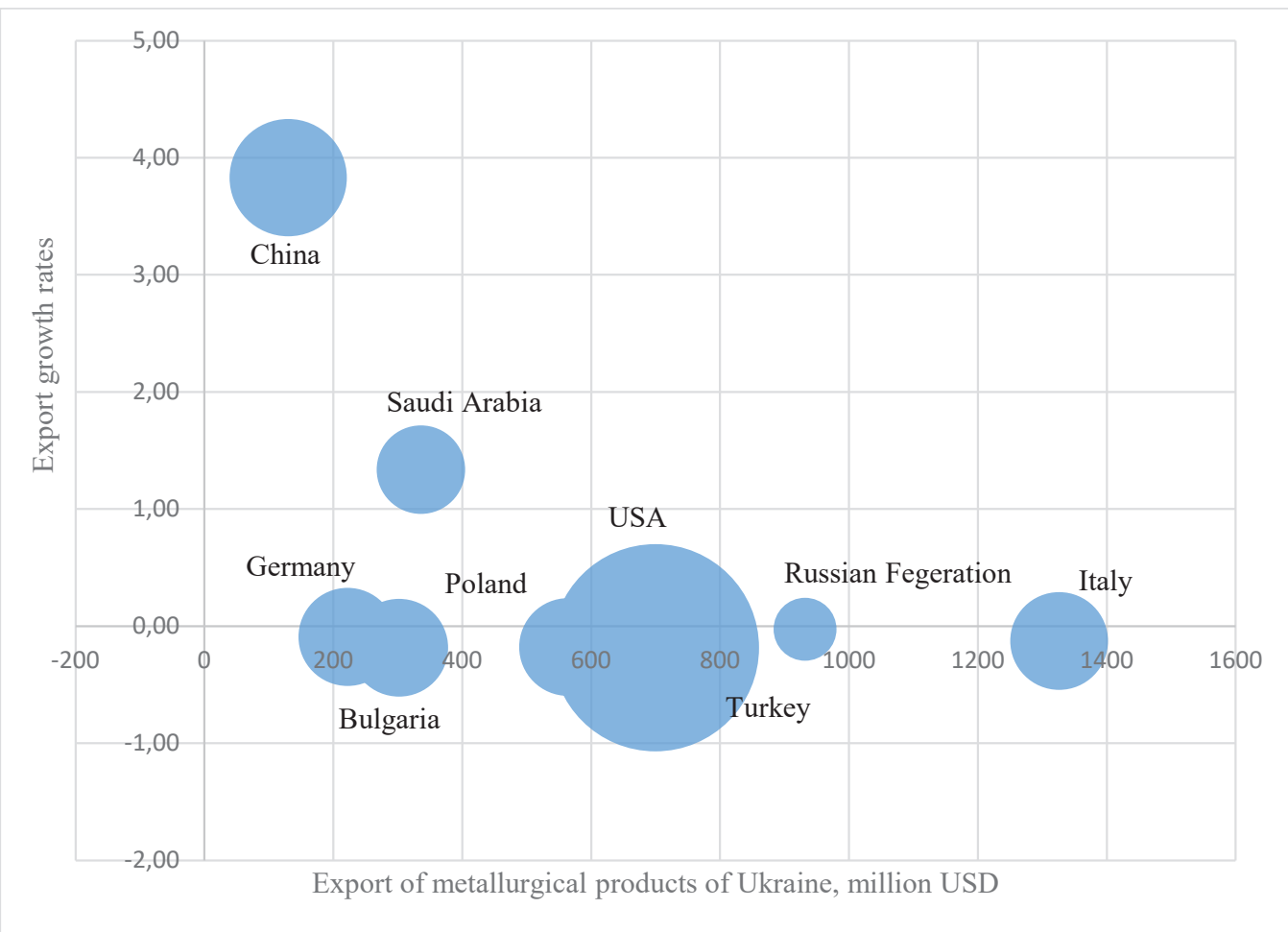

Figure 6. Matrix of countries-importers of Ukrainian metallurgical products and the number of introduced non-tariff customs barriers in 2019

\section{Conclusions}

The metallurgical industry is strategically important for Ukraine's economy, as it is one of the key products of exports, an industry that generates a significant share of Ukraine's budget revenues, an industry that generates a significant number of jobs. The high volatility of exports of metallurgical products indicates a high dependence on external factors and is a risk to Ukraine's economic security and stable trade balance.

One of the most important factors influencing the international activity of enterprises of the metallurgical industry of Ukraine are trade barriers to metal products. This tool has a positive dynamic in the number of applications since 2016. According to the number of trade barriers in the cross-section between sectors of the economy, the largest number falls on the metallurgical industry.

That is why it is proposed to use a matrix of the interaction of the number of trade barriers and export volumes by partner countries. This tool will identify the riskiest areas of international trade and promising areas of development. According to the results of our study, in Figure 6 formed this matrix. The conclusions to this matrix identified the riskiest areas of international trade (USA and Russia), medium risk areas (Poland, Bulgaria, Germany) and the most promising areas of international trade (Italy and Saudi Arabia).

With the help of this matrix, it is possible to identify countries, trade with which may pose a potential risk for Ukrainian producers. This risk is manifested in the growth of activities aimed at protecting the domestic market and national producers. These factors should be compared with the weight of each individual country in the international trade of Ukraine. Thus, the main goal of this method and matrix is to determine the strategic directions of development and reorientation of current trade flows.

\section{References:}

Novikov, M., \& Zemlyanskaya, S. (2021). The system of customs and tariff regulation of the EAEU in the context of globalization: problems, trends and prospects of development. SHS Web of Conferences, vol. 92.

Shirinova, A. (2018). On the issue of the application of FEA (foreign economic activity) non-tariff regulation instruments in the context of the WTO (World Trade Organization) regulations. Bulletin of Taras Shevchenko National University of Kyiv Public Administration, 1(10), 56-62.

World Steel Association (2019). The World Steel Association Report 2019. Geneva, 2019.

World Bank (2021). Global Economic Prospects 2021. USA, June 2021.

State Statistics Service of Ukraine (2020). Ukraine`s Foreign Trade 2020. Ukraine, 2021.

World Trade Organization (2021). World Trade Statistical Review 2021. Geneva, 2021. 